\title{
The European Union Integration Process and the Place of Turkey
}

\author{
Tülay Yıldırım \\ Yeni Yüzyıl University, Turkey \\ E-mail: yildirimtulay@hotmail.com
}

\section{Doi:10.5901/ajis.2013.v2n8p740}

\begin{abstract}
The European Union integration project, established to enlarge the political structure and power of the EU, has rapidly evolved according to the changing dynamics of the international system and has developed different strategies over time due to the problems accrued in the decision-making mechanism of the EU and the institutional weight brought by new members. Turkey has tried for inclusion into this process for fifty-four years with its application to the European Economic Community. The historical relationship between Turkey and the EU should be viewed as a challenging ideological engagement. Since the Ankara Agreement was signed in 1963, there have been some changes in political expectations on both sides, but the fact remains that neither Turkey nor the EU has desired to end this process. This paper evaluates Turkish-EU relations from the perspective of the integration process.
\end{abstract}

Keywords: European Integration, European Union, Turkey, Enlargement, EU-Turkey Relations

\section{Introduction}

The experience of endless wars for hundreds of years and the tragedies of the Second World War forged a desire among the European countries to integrate and cooperate so as to deflect future tragedies. The major purposes of the cooperation were to re-build the countries and cities economically, socially, and politically that were damaged during the wars, and to stop the possibilities of future wars. There were two primary creators of the cooperation/integration project in Europe: France and Germany. Their first attempt was the Paris Agreement, which was signed in 1951 by France, West Germany, Italy, Belgium, Holland and Luxembourg. From that agreement, the European Coal and Steel Union emerged and the second attempt was the Rome agreement, which was signed by the same countries. Based on that agreement, the European Economic Community and European Atomic Energy Union were established.

Evolving through time, this movement of economic unity grew to become a very important political structure. Since the foundation of modern Republic in 1923, Turkey had consistently turned toward Europe in attempts to join to the Western European Union. In July 1959, Turkey submitted an application to join the Union for the first time. This date was a milestone, though Turkey had been taking roles in almost all of Europe's political, economic and military institutions. Turkey desired to become part of the growing European projects, considering them as inevitable, transformationally significant, and socially evolutionary in its own process of Westernization. Based on Turkey's ideal of Westernization, the first part of this paper will discuss Turkey's journey in the process and the obstacles it has faced in attempting to join the EU. It will also discuss how the EU has perceived Turkey's attempts and attitudes toward being a player in the integration process.

It should be noted that the naming of the "European Union" varies in different literature. Prior to 1967, the European Economic Community (EEC), the European Coal and Steel Union, and the European Atomic Energy Union were united under one umbrella: the EEC. From 1967 to 1993, it was known as the European Community (EC); following the Maastricht Agreement, it became known as the European Union (EU).

\section{European Integration Process}

The idea of a European Integration Process dates to the $11^{\text {th }}$ century and marked a desire to bring all the European states together for peace. In other words, most European thinkers had been considering ways to create a united European state formed by all European countries for centuries. They could finally adopt and practice that idea after the Second World War because of the emerging social and political climate (Nugent, 2006, p.13).

In 1306, Pierre Dubois, in his book named Saving Holy Land, discussed this idea with the leadership of the Pope, 
the idea that it would be possible to provide peace in Europe through Christian unity (Özkan, 2011, p.31). In 1623, Emeric Crucé suggested that the problems and conflicts among the European States could be solved based on fair decisions made by a group of monarchical representatives that would meet regularly (Meray, 1977, p.29). In 1693, William Penn, in his book Europes's Peace for Now and the Future, offered to found a European Parliament in which Ottoman and Russian representatives could also participate as a way of resolving conflicts based on consensus (Meray, 1977, p.31). All of these attempts, however, to unite the Continent remained as mere mental speculation until the Second World War, at which time similar actions and ideas continued and were judged worthy of implementation owing to new forms of domination. It should not be forgotten that the political attempts of Napoleon and Hitler should, ironically, be considered as parts of actions meant to unite Europe, also (though their methods and tools were different). Their political actions and ideals, of course, to stage European integration resulted in disaster. After the Second World War, the continent was divided into East and West with the Soviet "Iron Curtain" militarily, economically, and ideologically. As a result, the continent became the political field of two powers: the United States and the USSR (Gürkaynak, 2004, p.11). This bitter experience of the ensuing Cold War put the idea of integration on hold, as the notion of singular domination had left a bitter taste on Europe's tongue. This historical moment forced political thinkers to consider new ways that European integration process might come about, ways which would be based on equal, free- willed and volunteered parameters.

After the Second World War, the European States feared that the main actor of the Second World War, Germany, would again rise as a threat for the Continent again and cause another war scenario (Mccormick, 2005, p.59). This fear, ironically, became the driving force to unite the European states. After the war, the major consideration at play in Europe's will to integrate was to control Germany's economic and military power and to pursue peace in Europe (Preston, 1997, p.185).

The European integration project (with the leadership of France, Germany, Italy, Belgium, Holland, and Luxembourg-Benelux) officially began after the signing of the European Coal and Steel Agreement (ECSA) in 1951. The purpose of this agreement was to remove the custom barriers for the coal and steel sectors. Because ECSA brought about a lot of successful results, European countries decided to expand the cooperation and redouble their efforts. As a result of this attempt for European integration, the founding countries formed the European Economic Union (EEU) and European Atom Energy Union (EURATOM) in 1957. These two new unions followed ECSA's principles and integrated "transnational" characteristics for the Continent. Founded initially for ECSA, the Parliament and Court of Justice also functioned for EURATOM and EUC. In 1965, the decision-making mechanism of these three unions was also combined and this development led to the formation of the European Community (EC). The EC became an international actor in the political arena. After these important developments, the European integration process gradually evolved toward "cooperating, trying to find middle ground and consensus on economic issues and finally uniting for common economic and political ideals" (Çiftçi, 2005, p.475). Today, it would not be wrong to say that the European integration process was a unique cooperation experience in the history of Europe and resulted in the European Union (EU) project as an ideal.

When we consider the decisions of Rome Agreement, we can see that the EEU wanted to build the Union on two important ideals: the addition of more European countries to the Union and to expand the Union geographically to emphasize possibilities and fields of cooperation (Preston, 1997, p.189). The European Union evolved with these two ideals. In the 1970s, the movements to realize these ideals were very encouraging for the Union in terms of integration, but still the aspect of geographic expansion as an ideal was slow and struggling to gain a foothold. For instance, French President Charles de Gaulle vetoed England, Denmark, and Ireland's application twice for inclusion in the European Economic Union (EEU).

De Gaulle moved away from the political scene in France and his absence resulted in multiple outcomes: the EEU no longer had to deal with France's barrier for the expansion of the union; also, the EEU displayed very successful economic cooperation and these developments encouraged additional political cooperation. In 1970, the European Political Cooperation Agreement was signed. The main purpose of this Agreement was to expand the integration movements from the economic to various other fields, and finally to add structural depth to the ideas of European integration (Dedeoğlu, 2003, p.45).

Following De Gaulle's withdrawal from politics, England, Denmark, and Ireland signed an agreement in January 1973 to join the EEU and they were accepted. Their inclusion-which increased the EEU's number of members to ninemeant that the EEU finally could expand geographically. This expansion is considered a milestone for the history of Europe's integration process. In 1981, Greece completed negotiation requirements and joined the EEU as a full member; this addition is also known as a critical turn in the expansion process for the Union. This development was received positively among member countries. Yet, for Turkey, a country that also aimed to join the Union, this was not a positive development. The reason is that, following Greece's membership in the Union, EEU left its political tradition to balance 
the relationship between Turkey and Greece. As a full member of the EEU, Greece continuously pressured Turkey regarding sensitive historical issues. This pressure caused Turkey's relationship with the EEU to sour, with Greece as a constant obstacle. Today, Greece's attitude toward Turkey is known as classic international politics.

In 1991, after the USSR collapsed, the international system underwent a drastic change, shifting from bi-polar international system to a new one. This bi-polar international system had been in power since the end of the Second World War. After undergoing a political paradigm shift, Europe was given the opportunity to become a global actor in the new world order. In order to become a real force for international security and peace, Europe needed to develop a multiple-sided economic, political, and military capacity. The Maastrich Agreement, signed in 1992, provided the framework for this capacity, and its purpose was to found the European Union.

According to this agreement, the EU would be built on three fundamentals: 1) Economic and Monetary Fundamentals, 2) Justice and Domestic Fundamentals, and 3) Common Foreign and Security Politics (Baun, 2000, p.74). Throughout the whole European Integration Process, the key fundamentals to build and maintain a "European United States" depended on "common foreign and security politics."

Following the Maastricht Agreement, two important issues emerged: one involved the need for the new EU to take in- depth, meaningful steps toward integration and the second was to include Eastern and Middle European countries in the integration process. The major reason for that was because those countries were important actors during the Cold War. Prior to reaching out to those Eastern and Middle European countries, the Union (in order to maintain and tighten the cooperation effectively without dissolving the Maastricht Agreement) signed the Amsterdam Agreement in 1997 (Caşın, Özgöker and Çolak, 2005, p.353). The Amsterdam Agreement brought to the fore new issues and developments regarding the European integration process, including democratization, employment policy, mutual freedom, foreign policy and security policy (Dedeoğlu, 2003, p.60).

In addition, the Nice Agreement was signed in 2003. It was also very crucial both strategically and symbolically prior to Eastern European inclusion, aiming to secure a number of important issues in the body of the Union (especially in terms of institutional structure and operation for the 25 member nations). Following the implementation of the Nice Agreement in May 2004, as had been planned, Czech Republic, Estonia, Southern Cyprus, Slovakia, Latvia, Lithuania, Hungary, Malta, Poland and Slovenia became full members of the European Union, giving the EU 25 members. The agreements discussed above, along with Eastern European expansion, allowed the EU to traverse its major geographic obstacle.

The most notable phase in the European integration process was the preparation of the constitution of the European Union. It should be emphasized that this phase was an important development in the process of building a "European United States." With the Laeken Summit decisions signed in December 2001, the draft of the constitution was prepared; it then gained legal eligibility with the Rome Agreements of July 2004. First, the draft of the constitution was submitted for approval by the national legislatures of the member states. Subsequently, the Rome Agreements would become effective after November 2006. With these developments, the EU hoped to have a legal and valid constitution.

In May 2005, the EU constitution was voted on with a plebiscite, and rejected by $54.87 \%$ of the electorate. Later, in Holland, the plebiscite took place once again, and again it was rejected by $61.8 \%$ of the electorate (Eralp and Şenyuva, 2011, p.83). As a part of the European integration process, the European constitution was very crucial. It came as a surprise that two important founding nations and their society citizens rejected the European constitution. The rejection of the constitution was considered a break and a shock in the process of European integration. It also revealed critical issues and debates regarding the European integration process itself, and impacted negatively on the entire structure of integration developments (Kuus, 2007, p.161). After this experience, the process went into a critical phase. The Lisbon Agreement-also called the Reform Agreement-was signed in October 2007, and was intended to move the integration process toward more clear and decisive actions (Baç, 2008, p.29). The EU added two former Eastern Bloc countries-Romania and Bulgaria-in January 2007, thereby increasing membership to twenty-seven states. This addition was considered to be a positive move within the expansion aspect of the integration process. Taking effect in 2007, the Lisbon Agreement is viewed as a revised version of the 2004 EU constitution. In July 2013, Croatia became the twenty-eighth member of the EU. These expansion policies of the EU were important in terms of getting over the cultural hegemony of the western European states in the EU and being more tolerant of different cultural structures and norms.

\section{Europe's Integration Process and Turkey}

Following the Second World War, Turkey chose to be on the side of Western allies, and to become a member of NATO. 
In July 1959, Turkey applied to the EEC for membership. Following this submission, all of Turkey's political aspirations and decisions were shaped by its desire for membership in the EEC. At the same time, Turkey's application raised important debates and issues regarding relations between itself and Europe. One of the major debates involved Turkey's geographical location. The EU Amsterdam Agreement (Article 49) stated that only European States could join to the Union (Berksoy, 1998, p.37). Regional characteristics of full membership were emphasized in terms of regional and geographical qualities. Ninety-five percent of Turkey's land mass is in Asia, while only five percent (Thrace) rests geographically on the European continent. Geography has thus been a major debate during Turkey's journey for European integration. This debate also shaped the nature of Turkey-EU relations. Framed by the Ankara Agreement, which was signed in 1963, the EU recognized Turkey as a European state (Vali, 1971, p.335), marking the first step toward the nation's European integration.

With Ankara Agreement the following intentions were declared by both sides: to tighten and enrich the relationship between Turkey and Europe; to develop Turkey's economy and life standards as it can be compatible with European economy through enriching relations; to decrease the economic and social differences between two sides; to help Turkey economically so that it can be a potential candidate of EEC for the future. In order for this happen, Turkey and EEC signed a protocol in 1970. After having the petrol crises in 1974, West Germany, Benelux Countries, and France required Visa from Turkish citizens in 1980. This development affected Turkey EEC relation negatively (Çayhan and Güney, 1996, p.100) In addition to economic crises, Turkish intervention in Northern Cyprus and 1980 coup also changed the direction and quality of the relations between Turkey and EC. This was the beginning of problematic relations between Turkey and EC. After 1980 coup in Turkey, EC became more distant and cautious about integration process.

Right after 1980, surprisingly Turkey expresses its desire to be a full member of EC as soon as possible. According to Çayhan and Güney (1996, p.102), the following developments motivated Turkey to not to change its direction and mission toward becoming a part of EU: Greece, Spain and Poland would become the full members of EU soon and this would put extra weight on Turkey in terms of competitiveness; changing dynamics in the region such as Iranian Revolution, and Soviet occupation in Afghanistan. Beginning with mid-1980s, Turkey too important steps in th integration process. For instance, although it would cause economic disadvantages for Turkey, it accepted Custom Union Agreement with heavy requirements which would never be asked to any candidate states. In late 1990s, Turkey did a lot of political and social reforms in terms of human rights.

Turkey experienced its major disappointment about EU in the mid 1990s. Some "Iron Curtain" countries which were behind of Ankara in many ways were considered as potential candidates for EU. Luxembourg Summit done by EU in 1997 was also a disaster for Turkey. Czech Republic, Slovakia, Hungary, Poland, Letonia, Estonia, Slovenia, Romania, Bulgaria, Latvia, Estonia and Southern Cyprus were chosen as candidate states in that Summit. Turkey was not even mentioned and Turkish public reacted against that. EU's rationale for that was about human rights violations, Cypress issue and Turkish-Greek conflicts. Turkey protested EU and suspended some relations with EU. Although there were positive steps taken toward Turkey's membership in Cardiff, Vienna and Koln Summits, Turkey's EU candidacy was declared officially in December 1999 at Copenhagen Summit. After that Turkey-EU relations faced with another problem durin 2000 s that negotiation frameworks and dates were not declared.

Turkey kept preparing reform packages and positive changes in the constitution. It also took serious responsibilities for Cyprus issue and accepted "Annan Plan." While Turkish Cypriots voted approved "Annan Plan," Greek Cypriots rejected the Plan.

EU always considered Turkey as an important partner in common security issues and foreign policy and they started negotiation process. In October 2005, the scanning procedure was done on Turkey and EU declared how Turkey is compatible with EU. With the help of this scanning, Turkey's responsibilities in the negotiation process became clear. This has to be emphasized that Turkey-EU relations would never break-off and they would continue integration process.

\section{Results}

For hundreds of years, the European integration project has been evolving both in theory and practice. Today, this project remains very crucial. The EU has 28 members, which means that nearly all of the European states are under its umbrella. The geographical scope reached bt the EU should be considered a big success. The economic and monetary gains of this integration have been perhaps the greatest achievement of the "European United States," and should be seen as an example of success for the rest of the world. Beginning with Father Pierre L'ermit's offer to unite all of the European states against Turks and Islam in the 11th century, this project has evolved and transformed dramatically. As an example, Turkey (at one time the enemy) and the EU began the membership negotiation process in 
2005. The EU has also been able to adapt and transform itself and its integration procedures based on changes in the international political system. After the Cold War, the "Iron Curtain" countries struggling with poor economic, political and social conditions were able to enter the EU within 14 years of the collapse of the USSR. Turkey, however, a nation that has been trying to enter for the last 54 years, still is not a member. According to Lucius Annaesus Seneca, "the one who does not know which door to enter cannot catch the right wind." By the late 1950s, Turkey knew which door to open, but as yet has not been able to catch the right wind.

\section{References}

Asmus, R. D., (2008) "Europe's Eastern Promise, Rethinking NATO and EU Enlargement", Foreign Affairs,, 87(1), pp.95-106

Baç, M., (2008), Turkey's Accession to the European Union: The Impact of the EU's Internal Dynamics", International Studies Perspectives, 9(2), pp.17-31.

Baun, M. J., (2000), A Wider Europe: The Process and Politics of European Union Enlargement, Lanham, Rowman and Littlefield Publishers.

Berksoy, T. (1998). Türkiye - Avrupa Birliği Iliş̧kilerinin Anatomisi, Marmara Üniversitesi Avrupa Topluluğu Enstitüsü Avrupa Araşıırmaları Dergisi, 6 (1), 31- 41.

Caşin, M. H., Özgöker U., Çolak H., (2007) Küreselleşmenin Avrupa Birliği Ortak Güvenlik ve Savunma Politikasına Etkisi, Avrupa Birliği, İstanbul.

Çayhan, E. ve Ateşoğlu G., (1996). Avrupa'da Yeni Güvenlik Arayışları: NATO-AB-Türkiye, Afa Yay.- Tüses Vakfı, İstanbul.

Çiftçi, S. (2005). Treaties, Collective Responses and the Determinants of Aggregate Support for European Integration, European Union Politics, 6(4), pp.469-492.

Dedeoğlu, B., (2003), Avrupa Birliği'nin Bütünleşme Süreci II: Avrupa Birliği'nin Yakın Geçmişi, Beril Dedeoğlu (der.), Dünden Bugüne Avrupa Birliği, İstanbul.

Dedeoğlu, B., (2011), Yeni Türkiye, Yeni AB. AB'deki Değişimin Üyelik Sürecine Etkisi, Haşimi, Cemal (Ed.), Türkiye, Avrupa ve Avrupa Birliği, İstanbul.

Eralp, A. (1996), Değişen Savaş-Sonrası Uluslararası Sistemde Türkiye ve Avrupa Topluluğu, Balkır, C. ve Williams, A.M. (der.) Türkiye ve Avrupa Illişkileri içinde Sarmal Yay., İstanbul, 37-63.

Gözen, R., (2006), Türk Dış Politikasının Avrupa Birliği'ne Doğru Dönüşümü, Uluslararası Hukuk ve Politika, 2(6), pp.17-31.

Gürkaynak, M. (2004). Avrupa'da Savunma ve Güvenlik, Ankara.

Kabalioğlu, H. (1999). Turkey and the European Union-Converging or Drifting Apart?, Marmara Journal of European Studies, 7(1-2), 109-165.

Karluk, R. S., (1998), Avrupa Birligi ve Türkiye, 5.Baskı, Beta Basım Yayım ve Dagıtım, İstanbul.

Karluk, R. S., (2000), Helsinki Zirvesi Kararları Sonrasında Türkiye'nin AB Üyeliği, Türkiye Sorunlarına Çözüm Konferansı III, 25-27 Ocak 2000, Ankara.

Kernic, F.,(2007), Review, European Security after 9/11, European Political Science,6(4), pp.380-398

Kuus, M., (2007), Something Old, Something New: Eastness in European Union Enlargement, Journal of International Relations and Development, 10(2), pp150-167

Mccormick, J. (2005). Understanding the European Union, A Concise Introduction, 3rd Edition, Palgrave Macmillan, New York.

Meray, S. L. (1977). Uluslararası Hukuk ve Örgütler, Ankara.

Nugent, N. (2006). The Government and Politics of the European Union, 6th Edition, Duke University Press Durham.

Oğuzlu, T., (2006) AB-Türkiye İlişkilerinde Nereye Doğru: Genişleme ve Reform Yorgunlukları Aşılabilecek mi?, Global Strateji, 2(7), pp. $115-132$

Özkan, I. (2011), Avrupa Birliği Kamu Hukuku, Seçkin yayınclık, Ankara.

Preston, C., (1997), Enlargement and Integration in the European Union, London, Routledge.

Redmond, J., (2007), Turkey and the European Union: Troubled European or European Trouble", International Affairs, 83( 2), pp.305317.

Tezcan, E., (2005), Avrupa Birliği Kurumlar Hukuku, Ankara. 